\title{
Amino acid requirements of pigs. 3. Requirement for apparent digestible threonine of pigs in different stages of growth
}

\author{
N. P. LENIS \& J. TH. M. VAN DIEPEN
}

Research Institute for Livestock Feeding and Nutrition, P.O. Box 160, NL 8200 AD Lelystad, Netherlands

Received 5 March 1990; accepted 9 May 1990

\begin{abstract}
The requirement for threonine of pigs was examined in feeding experiments on individually housed pigs in the live weight range 45 to $105 \mathrm{~kg}$ and on group-housed pigs in the live weight range 65 to $95 \mathrm{~kg}$. Lysine supply corresponded with the lysine requirement of growingfinishing pigs. To a negative control diet, containing $134 \mathrm{~g} \mathrm{~kg}^{-1}$ crude protein and $4.5 \mathrm{~g}$ $\mathrm{kg}^{-1}$ threonine, three levels of supplements of $\mathrm{L}$-threonine $\left(0.6,1.2\right.$ and $\left.1.8 \mathrm{~g} \mathrm{~kg}^{-1}\right)$ were tested. These results were compared with those of a positive control diet containing $152 \mathrm{~g}$ $\mathrm{kg}^{-1}$ crude protein and $5.7 \mathrm{~g} \mathrm{~kg}^{-1}$ threonine. To prevent other amino acids than threonine to be limiting, the negative control diet was supplemented with lysine, methionine, tryptophan, isoleucine, histidine and valine. The positive control diet was only supplemented with lysine and methionine. The requirement for total threonine of growing-finishing pigs for maximum growth performance was found to be approximately $5.6 \mathrm{~g} \mathrm{~kg}^{-1}$ in a diet containing 9.4 MJ $\mathrm{NE}_{\mathrm{f}} \mathrm{kg}^{-1}$. This figure corresponds with approximately $4.7 \mathrm{~g} \mathrm{~kg}^{-1}$ apparent faecal digestible threonine and $4.3 \mathrm{~g} \mathrm{~kg}^{-1}$ apparent ileal digestible threonine. There was no significant difference in response between the growing and the finishing pigs. The requirement for ileal digestible threonine, relative to ileal digestible lysine requirement, was approximately $64 \%$. It appeared, that dietary protein levels can be reduced with 2 percentage units without any disadvantageous effect on growth performance, when limiting amino acids are supplemented sufficiently.
\end{abstract}

Keywords: pigs, threonine, lysine, requirement, ileal digestibility, ideal protein

\section{Introduction}

It is generally accepted to base individual amino acid requirements of piglets and growing-finishing pigs upon the ideal protein concept. This concept refers to an optimum pattern of dietary amino acids in exactly the proportions in which they are required by the pigs, resulting in a high utilization of dietary protein (Cole, 1978; Fuller, 1978; Cole et al., 1980; Henry, 1980; Low, 1980). The Agricultural Research Council (ARC) (1981) estimated the optimum dietary amino acid pattern for growing pigs from a range of disparate studies on pigs in the range $20-60 \mathrm{~kg}$ live weight 
(a.o. Fuller et al., 1979; Lewis \& Cole, 1976), augmented by data on the amino acid composition of body tissues.

Recently, Wang \& Fuller (1989) and Fuller et al. (1989) determined the optimum dietary amino acid pattern for growing pigs in nitrogen balance experiments with pigs of about $40 \mathrm{~kg}$ live weight. For threonine, Wang \& Fuller (1989) derived a requirement of $72 \%$ relative to total lysine $(=100 \%)$. This is substantially higher than $60 \%$ as reported by ARC (1981). Fuller et al. (1989) derived from separate estimates for requirements for both maintenance and protein accretion an optimum lysine threonine/lysine ratio of $75 \%$ for a rate of $\mathrm{N}$ accretion of $1 \mathrm{~g} \mathrm{~kg}^{-1}$ body weight ${ }^{0.75} \mathrm{~d}^{-1}$. Günther \& Badewien (1987) and Lenis et al. (1990) concluded from feeding experiments on growing pigs a threonine requirement of 65 and $66 \%$ respectively relative to lysine. However, for piglets in the weight range 6-15 kg, Lewis \& Peo (1986) found a threonine requirement of only $55 \%$ of the lysine level. Rosell \& Zimmerman (1985) derived for piglets in the same weight range a threonine requirement of $60 \%$ relative to lysine, whilst Gatel \& Fekete (1989) concluded 65$70 \%$ for weaned piglets in the live weight range $10-25 \mathrm{~kg}$.

Some of the discrepancies between the references were related to a too low dietary concentration of lysine for some categories of pigs. Another reason for variation could be that the optimum threonine/lysine ratio varies with age and rate of growth or protein accretion, since the threonine requirement for maintenance seems to be relatively high (Fuller et al. 1989). Variation is also due to the fact that up to now amino acid requirements have not been expressed as digestible amino acids. Faecal digestibility of amino acids helps to bring amino acid supply into better balance with amino acid requirements, i.e. for lysine and methionine + cystine (Lenis, 1989). Expressing requirements as ileal digestible amino acids should further improve accuracy of estimating amino acid balance, especially for threonine, as threonine relatively to lysine is poorly digested at the ileal level in several feedstuffs (Lenis, 1983; Van Weerden et al., 1985; Sauer \& Ozimek, 1986).

With the widespread trend for reduction of protein levels and inclusion of more synthetic amino acids for improved $\mathrm{N}$ utilization, it is important to apply a proper and precise balance between amino acids.

The experiments described here were designed for growing pigs in the weight ranges $45-105$ and $65-95 \mathrm{~kg}$ to estimate the threonine requirements relative to lysine, expressed at both ileal and faecal digestible basis. Secondly the assumption that the requirement for ileal digestible threonine relative to the requirement for ileal digestible lysine is the same in young pigs and older growing pigs was examined. Therefore a comparison was made with similar experiments on young pigs between $19-40 \mathrm{~kg}$ live weight (Schutte et al., 1990).

\section{Material and methods}

Two feeding trials were carried out on individually housed pigs in the live weight range $45-105 \mathrm{~kg}$ (Experiment 1) and two feeding trials on group-housed pigs in the live weight range $65-95 \mathrm{~kg}$ (Experiment 2). In all trials the same experimental treatments ( = diets) were applied. Experimental design i.e. the threonine/lysine ratio in 
the diets, was similar to that of experiments with young pigs as described by Schutte et al. (1990). The proportions of feedstuffs in the diets in their experiments corresponded as much as possible with those in the experiments described here, by using the same batches of feedstuffs.

\section{Animals and housing}

Both experiments were carried out at the Experimental Farm for Pig Production at Raalte. In both experiments, all animals $(\mathrm{GY} \times(\mathrm{GY} \times \mathrm{NL}))$ were born and raised at the Experimental Farm. In each experiment, at about $25 \mathrm{~kg}$ live weight, the animals were assigned to five experimental treatments according to a randomized block design, considering initial weight and litter association.

Each trial in Experiment 1 comprised 64 individually housed pigs, 32 barrows and 32 gilts. Each pen had a partly slatted floor, a feeding trough in the front and a nipple drinker in the back of the pen. Each block consisted of pigs of one sex only. In both trials there was one incomplete block of four animals.

In Experiment 2 the trials were carried out in two similar pig houses simultaneously. Each trial comprised 80 group-housed pigs, 40 barrows and 40 gilts: five pens with eight barrows and five pens with eight gilts. The total number of pigs in each experimental group was 32 . All pens had partly slatted floors. There was one dryfeed hopper per pen with a nipple drinker in the back of the pen. In this experiment a block consisted of five pens with pigs of the same sex.

In both experiments the pig unit was ventilated and artificially heated up to a temperature which was always above the minimum critical temperature.

\section{Experimental design}

In all trials, two basal diets, 1 and 2, were used. Basal diet 1 was used as a positive control and contained $152 \mathrm{~g} \mathrm{~kg}^{-1}$ crude protein and $5.7 \mathrm{~g} \mathrm{~kg}^{-1}$ total threonine. Basal diet 2, the negative control diet, contained $134 \mathrm{~g} \mathrm{~kg}^{-1}$ crude protein and 4.5 $\mathrm{g} \mathrm{kg}^{-1}$ total threonine. This diet was supplemented with $0.6,1.2$ and $1.8 \mathrm{~g} \mathrm{~kg}^{-1}$ synthetic L-threonine to obtain the diets 3, 4 and 5, respectively. Treatments and the analysed concentration of threonine and lysine, as well as the threonine/lysine ratios in the diets are given in Table 1.

Table 1. Treatments and analysed concentration of threonine and lysine in the diets of the experiments.

\begin{tabular}{lllll}
\hline Diet & Treatment & $\begin{array}{l}\text { Threonine } \\
\left(\mathrm{g} \mathrm{kg-1}^{-1}\right.\end{array}$ & $\begin{array}{l}\text { Lysine } \\
(\mathrm{g} \mathrm{kg}-1)\end{array}$ & $\begin{array}{l}\text { Ratio } \\
\text { threonine:lysine }\end{array}$ \\
1 & Basal diet 1 & 5.7 & 8.4 & 68 \\
2 & Basal diet 2 & 4.5 & 8.5 & 53 \\
3 & Basal diet 2 & 5.1 & 8.5 & 60 \\
4 & Basal diet 2 ++ & 5.7 & 8.5 & 67 \\
5 & Basal diet 2 +++ & 6.3 & 8.5 & 74 \\
\hline
\end{tabular}


In both experiments, feed intake, daily gain and feed conversion ratio were the response criteria to various threonine levels. In Experiment 1 also the effect on meat/fat ratio was measured, after slaughtering the animals at about $105 \mathrm{~kg}$.

\section{Diets and feeding}

Before preparing the diets, the feedstuffs were analysed for proximate components and for amino acids. Collection of samples of the diets and chemical analyses were performed according to the same procedure as described by Lenis et al. (1990). The proportions of feedstuffs and chemical composition of the basal diets 1 and 2 are given in Table 2. The amino acid composition of the two basal diets is presented

Table 2. Proportion of feedstuffs and analysed chemical composition of the basal diets 1 and $2\left(\mathrm{~g} \mathrm{~kg}^{-1}\right)$.

Diet 1

Diet 2

Feedstuff

Manioc

Maize

146.8

Soya flour

105

Maize gluten meal

55

Alfalfa

$55 \quad 55$

Skim milk powder

60

25

Cane molasses

30

Soya oil

Limestone

Dicalciumphosphate

Salt

Other minerals and vitamins 1

18

5

12.5

3

1.3

L-lysine $\mathrm{HCl}(78 \%$ )

DL-methionine

0.1

L-tryptophan

L-histidine

L-valine

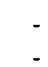

Analysed content

Crude protein

Ash

Crude fat

Crude fibre

Net energy ( $\mathrm{MJ} \mathrm{kg}^{-1} \mathrm{NE}_{\mathrm{f}}$ )

$\mathrm{Ca}$

1 The composition of the vitamin/mineral premix was identical to the premix used in the experiments, described by Schutte et al. (1990), except for $\mathrm{Cu}, \mathrm{Fe}$ and Tylosine. 
in Table 3. The lower protein and threonine level in basal diet 2 was achieved by exchanging $5 \%$ soya flour, $5 \%$ barley and $1 \%$ skim milk powder for mainly manioc. In both diets, substantial amounts of synthetic amino acids were included. In diet $1,28 \%$ of the lysine originated from L-lysine $\mathrm{HCl}$. Diet 2 was even supplemented with $49 \%$ L-lysine $\mathrm{HCl}$ and further with DL-methionine, L-tryptophan, L-isoleucine, L-histidine and L-valine to prevent these amino acids to be limiting in the diet. The chemical composition of the diets 3,4 and 5 was equal to that of basal diet 2, except for threonine, as before supplementing with L-threonine, these diets have been mixed together with basal diet 2 as one batch in order to get uniform diets. All diets contained $35 \mathrm{ppm} \mathrm{Cu}$ in the form of copper sulphate and $20 \mathrm{ppm}$ tylosine.

In both experiments the pigs were fed ad libitum. The diets were pelleted and given as dry feed in the trough (Experiment 1) or in the dry-feed hopper (Experiment 2). Water was available ad libitum.

Up to about $45 \mathrm{~kg}$ live weight the pigs were fed a starter feed ad libitum. Then the animals in Experiment 1 were switched to the experimental diets. The animals in Experiment 2 were fed a commercial fattening feed ad libitum up to the start of the experimental period at about $65 \mathrm{~kg}$ live weight.

The composition of the starter feed was as follows: crude protein $180 \mathrm{~g} \mathrm{~kg}^{-1}$, faecal digestible lysine $10.3 \mathrm{~g} \mathrm{~kg}^{-1}$, faecal digestible methionine + cystine $6.0 \mathrm{~g}$ $\mathrm{kg}^{-1}$, net energy 9.4 $\mathrm{MJ} \mathrm{NE}_{\mathrm{f}}$. The composition of the commercial fattening feed, fed up to $65 \mathrm{~kg}$ in Experiment 2, was: crude protein $155 \mathrm{~g} \mathrm{~kg}^{-1}$, faecal digestible lysine $7.5 \mathrm{~g} \mathrm{~kg}^{-1}$, faecal digestible methionine + cystine $4.8 \mathrm{~g} \mathrm{~kg}^{-1}$, net energy 9.05 MJ NE .

Table 3. Analysed amino acid concentration of the basal diets 1 and $2\left(\mathrm{~g} \mathrm{~kg}^{-1}\right)$.

\begin{tabular}{lrr}
\hline Amino acid & Diet 1 & Diet 2 \\
Isoleucine & & 6.0 \\
Leucine & 6.1 & 12.8 \\
Lysine & 14.4 & 8.5 \\
Methionine & 8.4 & 3.3 \\
Cystine & 2.9 & 2.2 \\
Phenylalanine & 2.6 & 6.4 \\
Tyrosine & 7.6 & 4.9 \\
Threonine & 5.5 & 4.5 \\
Tryptophan & 5.7 & 1.7 \\
Valine & 1.6 & 6.6 \\
Arginine & 7.8 & 6.3 \\
Histidine & 8.0 & 3.5 \\
Alanine & 3.6 & 7.3 \\
Aspartic acid & 8.2 & 9.6 \\
Glutamic acid & 12.3 & 25.3 \\
Glycine & 29.6 & 4.6 \\
Proline & 5.6 & 9.4 \\
Serine & 11.1 & 6.7 \\
\hline
\end{tabular}




\section{Measurements}

In Experiment 1, live weight and feed intake of the pigs were recorded weekly. After slaughter percentage of meat and fat in the carcasses have been determined according to the HGP-method. In Experiment 2, only on the first and the last day of the experimental period, the pigs have been weighed twice for reasons of accuracy. Feed intake was recorded over the whole period.

Apparent ileal and faecal digestibility of threonine and lysine of the basal diets 1 and 2 were derived from digestibility data of the similar diets A and B in the studies with young pigs, reported by Schutte et al. (1990) (Table 4). From this, concentrations of apparent ileal and faecal digestible threonine and lysine in the basal diets 1 and 2 were calculated (Table 5). From the concentrations of total, ileal and faecal digestible threonine and lysine the respective threonine/lysine ratios have been calculated and also presented in Táble 5 .

The net energy content of the basal diets 1 and 2 was calculated from their chemical composition and from faecal digestibility of proximate components in the similar diets A and B (reported by Schutte et al., 1990), according to the Rostock method (CVB, 1988).

Table 4. Estimates of apparent ileal and faecal digestibility (\%) of threonine and lysine of the basal diets 1 and 2, derived from Schutte et al. (1990).

\begin{tabular}{llllll}
\hline Diet & \multicolumn{3}{l}{ Threonine } & & \multicolumn{2}{l}{ Lysine } & \\
\cline { 2 - 3 } \cline { 5 - 6 } & ileal & faecal & & ileal & faecal \\
& 75.7 & 83.3 & & 87.7 & 89.5 \\
2 & 71.4 & 80.3 & & 88.4 & 90.1 \\
\hline
\end{tabular}

Table 5. Concentration of total, faecal and ileal digestible threonine and lysine ( $\left.\mathrm{g} \mathrm{kg}^{-1}\right)$ and threonine: lysine ratios in the experimental diets.

\begin{tabular}{lccccc}
\hline & \multicolumn{1}{c}{ Diet } & & & & \\
\cline { 2 - 6 } & 1 & 2 & 3 & 4 & 5 \\
Total lysine & 8.4 & 8.5 & 8.5 & 8.5 & 8.5 \\
Total threonine & 5.7 & 4.5 & 5.1 & 5.7 & 6.3 \\
Ratio total thre./lys. & 68 & 53 & 60 & 67 & 74 \\
Faec. dig. lys. & 7.5 & 7.7 & 7.7 & 7.7 & 7.7 \\
Faec. dig. thre. & 4.7 & 3.6 & 4.2 & 4.8 & 5.4 \\
Ratio faec. dig. thre./lys. & 63 & 47 & 55 & 62 & 70 \\
Ileal dig. lys. & 7.4 & 7.5 & 7.5 & 7.5 & 7.5 \\
Ileal dig. thre. & 4.3 & 3.2 & 3.8 & 4.4 & 5.0 \\
Ratio il. dig. thre./lys. & 59 & 43 & 51 & 59 & 67 \\
\hline
\end{tabular}




\section{Statistical analyses}

Experimental data were subjected to analysis of variance procedures appropriate for randomized complete-block design with sex and the amino acid under study as treatment factors, using the statistical package GENSTAT 5 (Payne et al., 1987). Treatment sums of squares were subdivided into linear, quadratic and cubic components. Treatment means were compared by Student's $t$ tests. For daily gain, feed intake and feed conversion ratio in Experiment 1, this was performed for the growing phase (up to $70 \mathrm{~kg}$ ), for the finishing phase (from $70 \mathrm{~kg}$ ) and for the whole experimental period. To estimate requirement figures, additional regression analysis was made for Experiment 1 according to a quadratic equation, and $95 \%$ confidence intervals were calculated.

\section{Results}

\section{Threonine/lysine ratios and feeding value}

Ratios of threonine/lysine on a total basis in the five diets ranged from 53 to $74 \%$. Ratios between faecal digestible threonine and lysine were 47 to $70 \%$ and between ileal digestible amino acids 43 to $67 \%$ (Table 5). The lower ratios on digestible basis are associated to a lower digestibility of threonine compared to lysine. Also a larger difference existed between ileal and faecal digestibility for threonine than for lysine, as reported by Lenis (1983), van Weerden et al. (1985) and Sauer \& Ozimek (1986).

Net energy content of the basal diets 1 and 2 (Table 2) was only slightly below the predicted value and rather similar to each other.

\section{Growth performance}

Two outliers were omitted from Experiment 1. In the analysis of variance the lacking data have been estimated as missing values.

Growth performance of the pigs in the trials 1 and 2 of Experiment 1 is presented in the Tables 6 and 7 . In Experiment 1 there was a sex $\times$ threonine $\times$ trial interaction for daily gain $(P=0.01)$ and feed conversion ratio $(P=0.02)$, making it questionable whether the results of trials 1 and 2 can be combined. However, since the residual variations between and within blocks for feed intake, daily gain and feed conversion ratio were almost equal for trials 1 and 2 , the results of both trials of Experiment 1 have been combined (Table 8).

Analysis of variance on the combined data showed weight gain of the pigs in the growing phase was significantly lower at a total dietary threonine level of $4.5 \mathrm{~g}$ $\mathrm{kg}^{-1}$. No differences in weight gain were observed between the other threonine levels. Threonine did not affect weight gain significantly in the finishing phase and in the whole experimental period. In the growing phase, threonine had a significant effect on feed conversion ratio $(P=0.006)$. A linear $(P=0.03)$ and quadratic $(P$ $=0.01)$ effect was found. The best feed conversion ratio was achieved at a total dietary threonine level of $5.7 \mathrm{~g} \mathrm{~kg}^{-1}$ in both barrows and gilts, but the improve- 


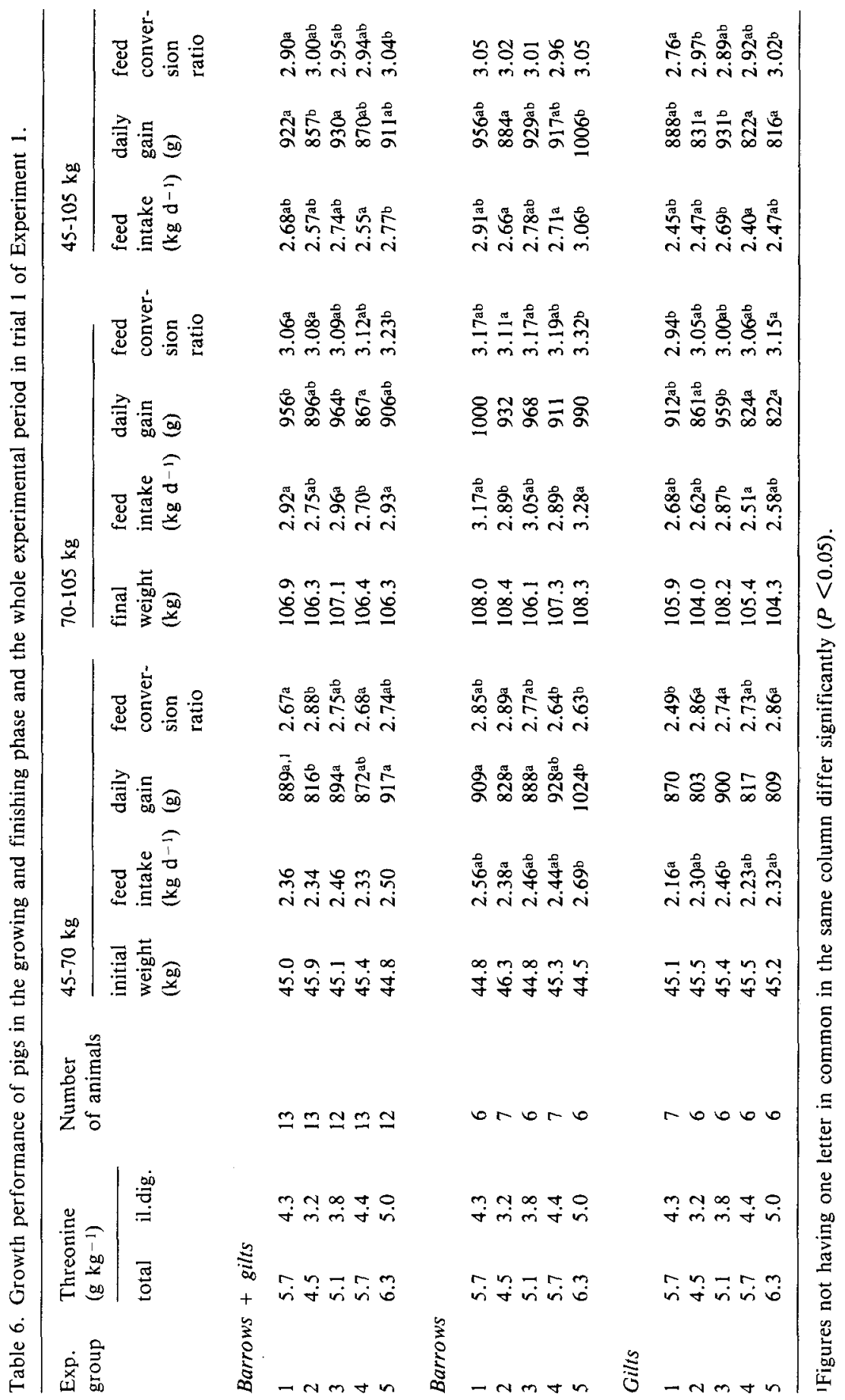




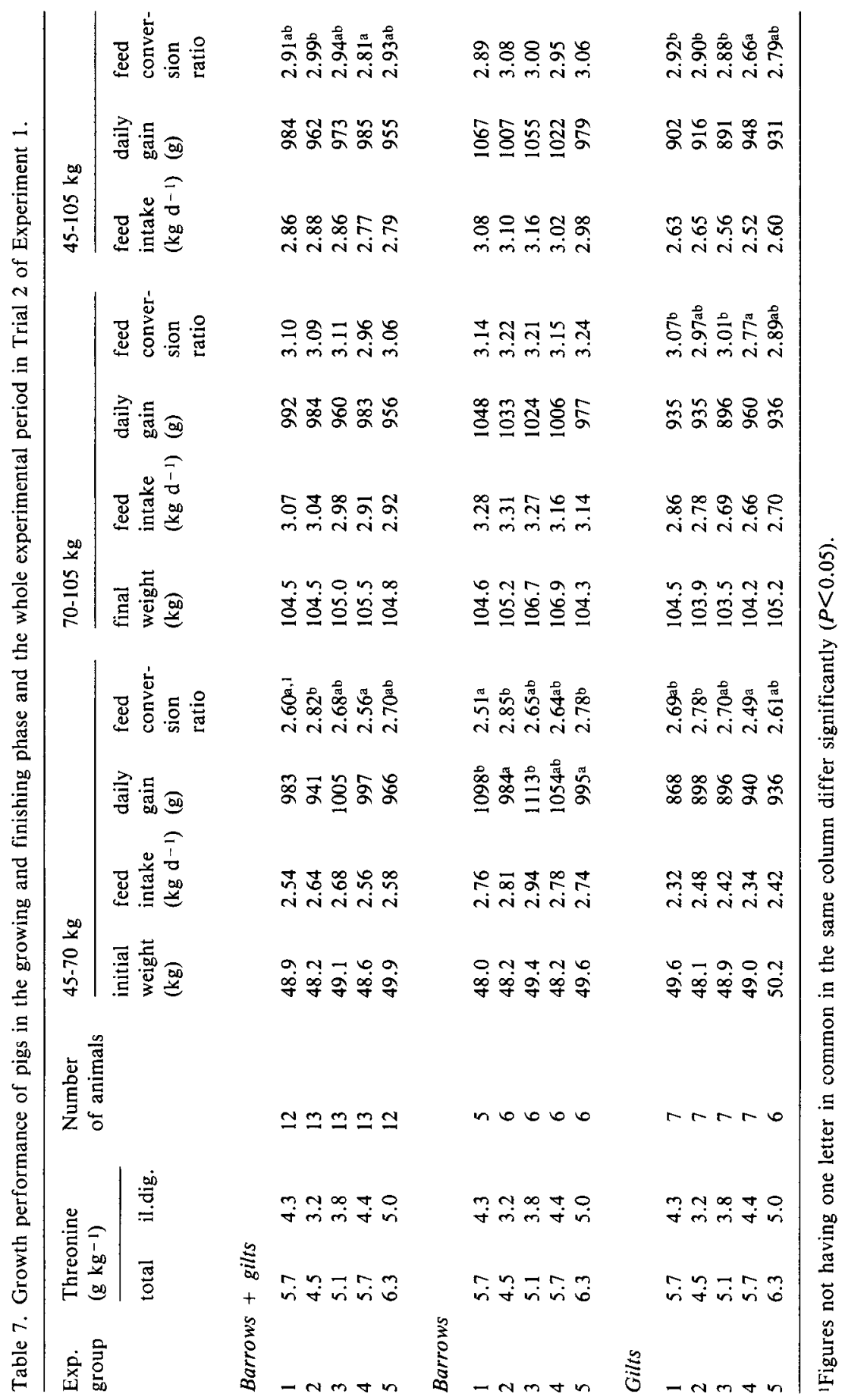

Netherlands Journal of Agricultural Science 38 (1990) 


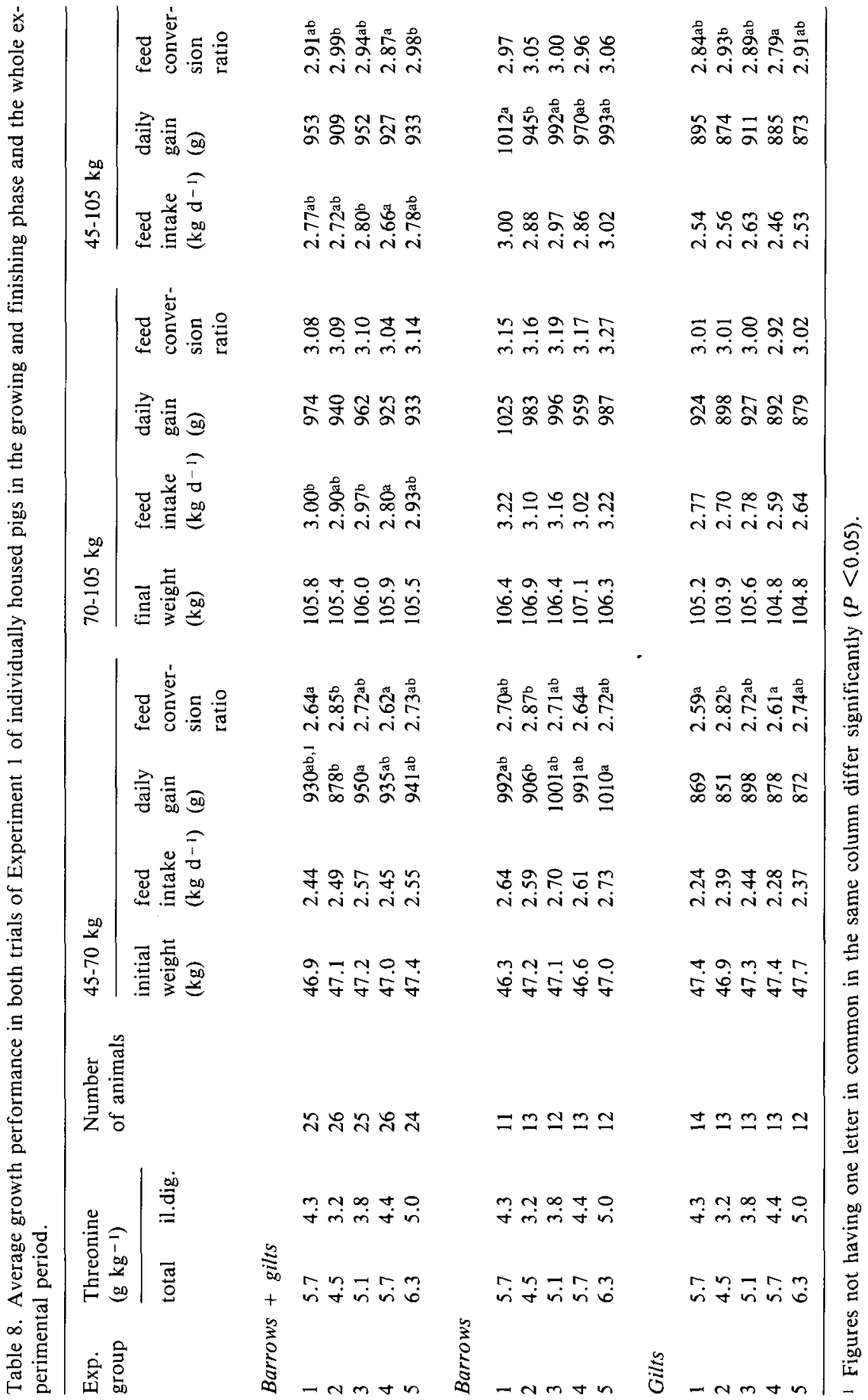


ment compared to a dietary level of $5.1 \mathrm{~g} \mathrm{~kg}^{-1}$ was not significant. In the finishing phase, feed conversion ratio was not affected by threonine in the barrows. In the gilts a small response was observed up to $5.7 \mathrm{~g} \mathrm{~kg}^{-1}$.

Feed conversion ratio of barrows + gilts over the whole experimental period was most favourable at a dietary threonine level of $5.7 \mathrm{~g} \mathrm{~kg}^{-1}$. This figure corresponds with $4.8 \mathrm{~g} \mathrm{~kg}^{-1}$ faecal digestible threonine and $4.4 \mathrm{~g} \mathrm{~kg}^{-1}$ ileal digestible threonine. Surprisingly, feed conversion ratio was significantly worse (quadratic effect, $P=$ 0.03 ) at the highest threonine level.

Feed intake of barrows + gilts was significantly lower at a dietary threonine level of $5.7 \mathrm{~g} \mathrm{~kg}^{-1}$, mainly due to a cubic effect of threonine upon feed intake in the finishing phase $(P=0.03)$. In both the growing and finishing phase, barrows were superior to gilts in daily gain and daily feed intake $(P<0.001)$; gilts were superior in feed conversion ratio in the finishing phase.

Table 9 shows the average carcass quality of the pigs of both trials of Experiment 1. Carcass quality of the pigs was not significantly affected by experimental treatment, but a trend for a lower meat percentage and a higher fat percentage was observed in carcasses of the highest threonine level. This observation corresponds with the worst feed conversion ratio in that group.

The combined results for growth performance of the group-housed pigs in the live weight range 65 to $95 \mathrm{~kg}$ in the trials 1 and 2 of Experiment 2 are given in Table

Table 9. Average carcass quality of the pigs of Experiment 1.

\begin{tabular}{|c|c|c|c|c|c|}
\hline \multirow[t]{2}{*}{$\begin{array}{l}\text { Exp. } \\
\text { group }\end{array}$} & \multicolumn{2}{|c|}{$\begin{array}{l}\text { Threonine } \\
\left(\mathrm{g} \mathrm{kg}^{-1}\right)\end{array}$} & \multirow[t]{2}{*}{$\begin{array}{l}\text { Killing out } \\
\text { percentage }\end{array}$} & \multirow[t]{2}{*}{$\begin{array}{l}\text { Meat } \\
\text { percentage }\end{array}$} & \multirow[t]{2}{*}{$\begin{array}{l}\text { Fat } \\
\text { percentage }\end{array}$} \\
\hline & total & il.dig. & & & \\
\hline 1 & 5.7 & 4.3 & 79.8 & 50.0 & 22.7 \\
\hline 2 & 4.5 & 3.2 & 80.0 & 50.0 & 22.7 \\
\hline 3 & 5.1 & 3.8 & 79.8 & 50.2 & 22.7 \\
\hline 4 & 5.7 & 4.4 & 80.0 & 50.3 & 22.0 \\
\hline 5 & 6.3 & 5.0 & 80.0 & 48.4 & 24.4 \\
\hline
\end{tabular}

Table 10. Average growth performance of group housed pigs (barrows + gilts) of Experiment 2 (average experimental period 33.3 days).

\begin{tabular}{|c|c|c|c|c|c|c|c|c|}
\hline \multirow[t]{2}{*}{$\begin{array}{l}\text { Exp. } \\
\text { group }\end{array}$} & \multirow{2}{*}{$\begin{array}{l}\text { Number } \\
\text { of } \\
\text { animals }\end{array}$} & \multicolumn{2}{|c|}{$\begin{array}{l}\text { Threonine } \\
\left(\mathrm{g} \mathrm{kg}^{-1)}\right.\end{array}$} & \multirow{2}{*}{$\begin{array}{l}\text { Initial } \\
\text { weight } \\
\text { (kg) }\end{array}$} & \multirow{2}{*}{$\begin{array}{l}\text { Final } \\
\text { weight } \\
\text { (kg) }\end{array}$} & \multirow{2}{*}{$\begin{array}{l}\text { Feed } \\
\text { intake } \\
\left(\mathrm{kg} \mathrm{d}^{-1}\right)\end{array}$} & \multirow{2}{*}{$\begin{array}{l}\text { Daily } \\
\text { gain } \\
\text { (g) }\end{array}$} & \multirow{2}{*}{$\begin{array}{l}\text { Feed } \\
\text { conver- } \\
\text { sion } \\
\text { ratio }\end{array}$} \\
\hline & & total & il.dig & & & & & \\
\hline 1 & 32 & 5.7 & 4.3 & 64.8 & 95.8 & 2.85 & 942 & $3.03^{\mathrm{b}, \mathrm{l}}$ \\
\hline 2 & 32 & 4.5 & 3.2 & 64.6 & 94.0 & 2.78 & 891 & $3.11^{\mathrm{b}}$ \\
\hline 3 & 32 & 5.1 & 3.8 & 64.6 & 95.0 & 2.79 & 923 & $3.02^{b}$ \\
\hline 4 & 32 & 5.7 & 4.4 & 64.8 & 96.7 & 2.71 & 968 & $2.80^{\mathrm{a}}$ \\
\hline 5 & 32 & 6.3 & 5.0 & 64.5 & 96.8 & 2.77 & 980 & $2.83^{\mathrm{a}}$ \\
\hline
\end{tabular}

1 Figures not having one letter in common in the same column differ significantly $(P<0.05)$. 
10. The results were in agreement with those in Experiment 1. Threonine did not affect daily gain significantly, although there was a trend for a lower growth rate at a total dietary threonine level of $4.5 \mathrm{~g} \mathrm{~kg}^{-1}$. Feed conversion ratio was significantly best at a total dietary threonine level of $5.7 \mathrm{~g} \mathrm{~kg}^{-1}$, corresponding with 4.8 and $4.4 \mathrm{~g} \mathrm{~kg}^{-1}$ faecal and ileal digestible threonine, respectively. Again feed intake was lowest (not significantly) at a dietary threonine level of $5.7 \mathrm{~g} \mathrm{~kg}^{-1}$.

\section{Discussion}

The concentration of (digestible) lysine and (digestible) other amino acids, except threonine (Tabel 3, Table 5), was assumed to be not limiting growth performance of the pigs (Lenis, 1989). Besides, no compensatory effects from the starter period in Experiment 1, or from the growing period in Experiment 2 have been assumed, as the diets offered in these periods were of a high nutritional value.

The results of the feeding experiments with pigs in the growing phase (45 to 70 $\mathrm{kg}$ ) of Experiment 1 and with pigs in the weight range 65 to $95 \mathrm{~kg}$ of Experiment 2 agree with each other. Minimum feed conversion ratio in both experiments was obtained at $5.7 \mathrm{~g} \mathrm{~kg}^{-1}$ total threonine and maximum daily gain at a dietary threonine level of $5.1 \mathrm{~g} \mathrm{~kg}^{-1}$ in a diet with $9.4 \mathrm{MJ} \mathrm{NE}_{\mathrm{f}}$. At the highest threonine level of $6.3 \mathrm{~g} \mathrm{~kg}^{-1}$ feed conversion ratio tended to worsen again, which was also found by Lenis et al. (1990) in the finishing phase. The similar threonine requirement for growing and finishing pigs can be explained from similar growth performance. It is to be expected that fat gain and protein gain and thus the amount of threonine needed, is almost equal in crossbred growing and finishing pigs. Feed intake, however is lower in growing pigs compared to finishing pigs. But because threonine requirement for maintenance is relatively high (Fuller et al., 1989), total threonine requirement expressed as $\mathrm{g} \mathrm{kg}^{-1}$ diet, is rather similar in growing and finishing pigs.

Concerning the whole experimental period (45-105 kg, Experiment 1), analysis of variance showed the best feed conversion ratio at a total dietary threonine level of $5.7 \mathrm{~g} \mathrm{~kg}^{-1}$. From regression analysis it was estimated that for obtaining both maximum weight gain and minimum feed conversion ratio, the dietary content of total threonine over the whole experimental period should be $5.5 \mathrm{~g} \mathrm{~kg}^{-1}$ (95 \% confidence interval 5.1-6.6 $\mathrm{g} \mathrm{kg}^{-1}$ ) with only minor differences between barrows and gilts. This figure corresponds with $4.6 \mathrm{~g} \mathrm{~kg}^{-1}$ faecal digestible threonine and $4.2 \mathrm{~g}$ $\mathrm{kg}^{-1}$ ileal digestible threonine. This estimate agrees with that of Lenis et al. (1990).

The estimate of total threonine requirement of growing/finishing pigs for maximum growth performance from this study (approximately $5.6 \mathrm{~g} \mathrm{~kg}^{-1} \mathrm{diet}$ ) expressed in proportion to total dietary lysine supply, amounted approximately $66 \%$. The corresponding optimum faecal and ileal digestible threonine/lysine ratio was approximately $61 \%$ and $58 \%$ respectively. However, dietary lysine supply was considered to be slightly above lysine requirement of the pigs (Lenis, 1989). If the requirement for ileal digestible lysine of growing/finishing pigs is supposed to be in the range $7.0-6.5 \mathrm{~g} \mathrm{~kg}^{-1}$ diet, the requirement for ileal digestible threonine (approximately $4.3 \mathrm{~g} \mathrm{~kg}^{-1}$ diet) as a percentage of ileal digestible lysine requirement is 
between 61 and $66 \%$. This is in agreement with the optimum threonine/lysine ratio on ileal digestible basis found in similar experiments on young pigs (Schutte et al., 1990), being between 63 and $66 \%$. The dietary level of ileal digestible lysine in those experiments $\left(9.1 \mathrm{~g} \mathrm{~kg}^{-1}\right)$ was supposed to correspond with the requirement for ileal digestible lysine.

From the results it is concluded that threonine requirement relative to that of lysine does not show significant differences between young pigs and older growing pigs. Application of the concept of the ideal protein system for both groups seems appropriate. However, our estimate is higher than the recommended threonine/lysine ratio on a total basis of ARC (1981), being $60 \%$, but lower than the estimate of Wang \& Fuller (1989), who found $72 \%$. The most recent estimate of Wang \& Fuller (1990) (64\% on a total basis) is only slightly lower than our estimate, which is in agreement with the estimate (66\% on a total basis) of Lenis et al. (1990) in a previous study.

Amino acid requirements can be expressed best as ileal digestible amino acids for amino acid evaluation (Herrmann et al., 1988; Dierick et al., 1988; van Weerden et al., 1989). Especially for threonine this is important, as threonine can be degraded in the hindgut to a large extent (Lenis, 1983). Therefore faecal digestibility is left out of consideration as a basis for expressing amino acid requirements. The requirement for apparent ileal digestible threonine for maximum growth performance, estimated from this study and from that on young pigs (Schutte et al., 1990), amounts approximately $64 \%$ relative to the requirement for ileal digestible lysine.

From both studies it appeared that dietary protein levels can be reduced with 2 percentage units without any disadvantageous effect on growth performance, when limiting amino acids are supplemented sufficiently. In Experiment 2, feed conversion ratio in the optimally supplemented diet was even better than on the positive control diet. In this study, dietary level of protein was reduced from 152 to $134 \mathrm{~g}$ $\mathrm{kg}^{-1}$, and in the study with young pigs (Schutte et al., 1990) from 185 to $160 \mathrm{~g}$ $\mathrm{kg}^{-1}$, contributing substantially to the reduction of $\mathrm{N}$ excretion by pigs.

\section{References}

ARC, 1981. The nutrient requirements for pigs. Commonwealth Agricultural Bureaux, Slough, $307 \mathrm{pp}$.

CVB, 1988. Table on feedstuffs. Information about composition, digestibility and feeding value. (In Dutch.) Centraal Veevoederbureau in Nederland, Lelystad.

Cole, D. J. A., 1978. Amino acid nutrition of the pig. In: W. Haresign \& D. Lewis (Eds), Recent advances in animal nutrition, p. 59-72. Butterworths, London.

Cole, D. J. A., H. T. Yen \& D. Lewis, 1980. The lysine requirement of growing and finishing pigs -the concept of an ideal protein. In: H. J. Oslage \& K. Rohr (Eds), Protein metabolism and nutrition, p. 658-668. European Association for Animal Production, Publication No. 27.

Dierick, N., I. Vervaeke, J. Decuypere, H. van der Heyde \& H. Henderickx, 1988. Correlation of ileal and faecal digested protein and organic matter to production performance in growing pigs. Wissentschaftliche Zeitschrift der Wilhelm-Pieck-Universität Rostock, Naturwissentschaftliche Reihe 37 (1): 23-24.

Fuller, M. F., 1978. Amino acids in the nutrition of the pig. Rowett Research Institute, Aberdeen, Annual Report 34, p. 116-128. 
Fuller, M. F., R. M. Livingstone, B. A. Baird \& T. Atkinson, 1979. The optimal amino acid supplementation of barley for the growing pig. 1. Response of nitrogen metabolism to progressive supplementation. British Journal of Nutrition 41: 321-331.

Fuller, M. F., R. McWilliam, T. C. Wang \& L. R. Giles, 1989. The optimum dietary amino acid pattern for growing pigs. 2. Requirements for maintenance and for tissue protein accretion. British Journal of Nutrition 62: 255-267.

Gatel, F. \& J. Fekete, 1989. Lysine and threonine balance and requirements for weaned piglets $10-25 \mathrm{~kg}$ live weight fed cereal-based diets. Livestock Production Science 23: 195-206.

Günther, K. D. \& E. Badewien, 1987. Zur Bedeutung von Methionin und Threonin in der Ernährung Ferkels und des Mastschweines bei Verwendung von Getreiderationen. Züchtungskunde 59: 378-391.

Henry, Y., 1980. Protein and amino acid requirements of growing pigs. In: H. J. Oslage \& K. Rohr (Eds), Protein metabolism and nutrition, p. 634-655. European Association for Animal Production, Publication No. 27.

Herrmann, U., J. Wunsche, M. Meinl, U. Hennig \& F. Kreienbring, 1988. Investigation on the precaecal nutrient digestibility and amino acid absorption in pigs fitted with ileo-rectal-anastomoses. Wissenschaftliche Zeitschrift der Wilhelm-Pieck-Universität Rostock, Naturwissenschaftliche Reihe 37 (1): 23-24.

Low, A. G., 1980. Amino acid use by growing pigs. In: W. Haresign (Ed.), Recent developments in animal nutrition, p. 141-156. Butterworths, London.

Lenis, N. P., 1983. Faecal amino acid digestibility in feedstuffs for pigs. In: R. Pion, M. Arnal \& D. Bonin (Eds), Proceedings 4th International Symposium on Protein Metabolism and Nutrition, Clermont-Ferrand (France), Vol. 2, p. 385-389. Institut de la Recherche Agronomique, Paris.

Lenis, N. P., 1989. Lower nitrogen excretion in pig husbandry by feeding: current and future possibilities. Netherlands Journal of Agricultural Science 37: 61-70.

Lenis, N. P., J. Th. M. van Diepen, \& P. W. Goedhart, 1990. Amino acid requirements of pigs. 1. Requirements for methionine + cystine, threonine and tryptophan of fast growing boars and gilts, fed ad libitum. Netherlands Journal of Agricultural Science 38: 577-595.

Lewis, D. \& D. J. A. Cole, 1976. Amino acid requirements. The Proceedings of the Nutrition Society 35: 87-91.

Lewis, A. J. \& E. R. Peo Jr., 1986. Threonine requirement of pigs weighing 5-15 kg. Journal of Animal Science 62: 1617-1623.

Payne, R. W., P. W. Lane, A. E. Ainsley, K. E. Bicknell, P. G. N. Digby, S. A. Harding, P. K. Leech, H. R. Simpson, A. D. Todd, P. J. Verrier, R. P. White, J. C. Gower, G. Tunnicliffe Wilson \& L. J. Paterson, 1987. Genstat 5 Reference Manual. Oxford University Press, New York, 749 pp.

Rosell, V. L. \& D. R. Zimmermann, 1985. Threonine requirement of pigs weighing 5 to $15 \mathrm{~kg}$ and the effect of excess methionine in diets marginal in threonine. Journal of Animal Science 60: 480-486.

Sauer, W. C. \& L. Ozimek, 1986. Digestibility of amino acids in swine: Results and their practical applications. A review. Livestock Production Science 15: 367-388.

Schutte, J. B., M. W. Bosch, N. P. Lenis, J. de Jong \& J. Th. M. van Diepen, 1990. Amino acid requirements of pigs. 2. Requirement for apparent digestible threonine of young pigs. Netherlands Journal of Agricultural Science 38: 597-607.

Wang, T. C. \& M. F. Fuller, 1989. The optimum dietary amino acid pattern for growing pigs. 1. Experiments by amino acid deletion. British Journal of Nutrition 62: 77-89.

Wang, T. C. \& M. F. Fuller, 1990. The effect of the plane of nutrition on the optimum dietary amino acid pattern for growing pigs. Animal Production 50: 155-164.

Weerden, E. J. van, 1989. Present and future developments in the protein/amino acid supply of monogastric animals. In: E. J. van Weerden \& J. Huisman (Eds), Nutrition and digestive physiology in monogastric farm animals, p. 89-101. Pudoc, Wageningen.

Weerden, E. J. van, J. Huisman, P. van Leeuwen \& P. Slump, 1985. The sensitivity of the ileal digestibility method as compared to the faecal digestibility method. In: A. Just, H. Jorgensen \& J. A. Fernandez (Eds), Proceedings 3rd International Seminar on Digestive Physiology in the Pig, Copenhagen, p. 392-395. National Institute of Animal Science, Copenhagen. 